\title{
Cognitive Function, Social Interaction, and Self Concept of Elderly Widows and Widowers
}

\author{
Dewi Sukma Nurul Aziz* \\ Department of Family and Consumer \\ Sciences, \\ Faculty of Human Ecology, \\ Bogor Agricultural University \\ *Corresponding author: dewisukma.nurul@gmail.com \\ Diah Krisnatuti \\ Department of Family and Consumer \\ Sciences, \\ Faculty of Human Ecology, \\ Bogor Agricultural University
}

\begin{abstract}
The elderly who are in the final stages of life, experience major changes such as physical, psychological, and social changes that can affect the instability of self-concept. This study aims to analyze the effect of cognitive function and social interaction on the self concept of elderly widow and widower. This research selected site in Timbulharjo Village, Sewon District, Bantul Regency, Yogyakarta which was chosen purposely with the consideration of the most populace areas of the elderly. The elderly in this study were elderly people that have aged over 60 years who had been abandoned by her partner more than or equal to two years. The number of examples in this study is 30 elderly widows and 30 elderly widowers. The results showed no differences in cognitive function, and social interaction between elderly widows and elderly widower, but there are differences in selfconcept between elderly widows and widower. In addition, age and duration of education have a relationship with cognitive function, and social interaction has a relationship with self-concept. Meanwhile, marital status has a negative effect and social interaction has a positive effect on elderly self concept so that the status of widow can decrease self concept of elderly, and the better social interaction hence the concept of elder self will be better.
\end{abstract}

Keywords: cognitive function, elderly widows and widowers, self concept, social interaction

Abstrak
Lanjut usia yang berada pada tahap akhir kehidupan, mengalami perubahan besar seperti perubahan fisik, psikologis, maupun sosial yang dapat memengaruhi ketidakstabilan konsep diri. Penelitian ini bertujuan untuk menganalisis pengaruh fungsi kognitif dan interaksi sosial terhadap konsep diri lansia janda dan duda. Penelitian ini bertempat di Desa Timbulharjo, Kecamatan Sewon, Kabupaten Bantul, Yogyakarta yang dipilih secara purposive dengan pertimbangan wilayah yang paling banyak jumlah penduduk lansia. Lansia dalam penelitian ini adalah lansia yang berusia lebih dari 60 tahun yang sudah ditinggalkan oleh pasangannya lebih dari atau sama dengan dua tahun. Jumlah contoh dalam penelitian ini sebesar 30 orang lansia janda dan 30 orang lansia duda. Hasil penelitian menunjukkan tidak ada perbedaan fungsi kognitif, dan interaksi sosial antara lansia janda dan lansia duda, namun terdapat perbedaan konsep diri antara lansia janda dan duda. Selain itu, usia dan lama pendidikan memiliki hubungan dengan fungsi kognitif, dan interaksi sosial memiliki hubungan dengan konsep diri. Sementara itu, status perkawinan berpengaruh negatif dan interaksi sosial berpengaruh positif terhadap konsep diri lansia sehingga status janda dapat menurunkan konsep diri lansia, dan semakin baik interaksi sosial maka konsep diri lansia akan semakin baik.

Keywords: fungsi kognitif, interaksi sosial, konsep diri, lansia janda, dan lansia duda 


\section{INTRODUCTION}

The number of elderly in Indonesia reached 21.68 million people with percentage of female elderly $(8.96 \%)$ more than male elderly $(7.91 \%)$ with men (Statistic Centre Agency 2015). Elderly women who have widow status will find it difficult to perform daily activities and experience loneliness, while the elderly men who hold the status of widower feel stronger, but thet have limitations in taking care of themselves so they were decided to remarried (Desiningrum 2014). The elderly who are in the final stages of life will experience a change in him, including the decline of physical, psychological, and social functions. The changes that occur in the entire system of the human body as in the nervous system that can lead to decreased brain function (Fadhia et al., 2012). The decreased of cognitive function is the factor that cause of the inability of the elderly in performing normal daily activities and become one of the reasons of the elderly's dependence on others to take care of himself. This situation can have an impact on the decrease of social interaction both in quality and quantity because the social role of elderly in society has been replaced by young generation. This will continue throughout life and cannot be avoided (Stanley \& Beare 2007 in Rosita 2012).

Decreased of social interaction of elderly can be caused by feelings of inferiority, guilt or useless, and the feeling of spouse lost (Setyowati 2013). The conditions like this, making the elderly close themselves from others and not interested to make social contact with others. In order to stay happy in the old days, the elderly must continue to interact with the social environment, remain active, able to take care of themselves independently, and not feel lonely and isolated (Sari 2012). Physical and psychological changes that occur in elderly widows and widowers will affect the instability of self-concept (Parwiti 2016). Instability of self concept is characteristic of elderly cannot adapt well in its environment. Based on the description above, research on the concept of elderly self becomes very important with considering the number of elderly population in Indonesia every year increasing so that more and more challenges will be faced by the elderly. Even, the study of self-concept elderly stilla lillte bit if associated with decreased cognitive function and social interaction in elderly widows and widower. By knowing the factors that affect the self concept of elderly, it is expected the elderly can improve the concept of himself into a positive self concept that can survive without having to rely on others. Based on the above explanation, this study aims to: 1) Identify differences in cognitive function, social interaction and self-concept of elderly widow and widower; 2) analyze the relationship of cognitive function and social interaction with the self concept of elderly widow and widower; 3 ) analyzing the effect of cognitive function and social interaction on the self concept of elderly widow and widower.

\section{RESEARCH METHOD}

This research use cross-sectional study design that is research done in one time. The site of this study is Timbulharjo Village, Sewon District, Bantul Regency, Yogyakarta Special Region that selected purposely by considering the Special Region of Yogyakarta has the highest number of elderly in Indonesia according to Civil Registry and Population Office 2015. Populations in this study were elderly widows and widowers aged 60 years and over who doesn't have partner for at least 
two years (Rathus \& Nevid 1991). The number of samples involved in this study were 60 elderly people consisting of 30 elderly widows and 30 elderly widower using random sampling technique. The data that obtained from the questionnaire of the characteristics of elderly that includes age, length of education, marital status, employment status, and income; cognitive function using MMSE (Mini Mental State Examination) questionnaire with total of 11 items consisting of orientation, registration, attention and calculation, recall, and language and comprehension; social interaction using questionnaires consisting of core family interaction dimension, sibling/ relative interaction, neighbor interaction, interaction of old friend, and social activity interaction with statement amount of 37 items; selfconcept of Fitts (1971) questionnaire with a total of 50 items consisting of dimensions of self-identity, self-image, self-ideal, self-esteem, and role.

Processing phase starts from the process of editing, coding, scoring, data entry, data cleaning, and data analysis using Microsoft Excel for Windows software and SPSS 16.0 for Windows software. Cut off cognitive functions include decreases $(<24)$ and normal $(\geq 24)$; social interaction using cut-off low $(<33.33)$, medium (33.33-66.67), and high (> 66.67); and self-concept using cut-off low $(<60)$, medium (60-80), high (> 80). Data analysis that used in this research is descriptive statistic and inferentia to find elderly characteristic covering age, length of education, marital status, work status, and income; different test by using independent sample T-test to analyze difference of elderly characteristic, cognitive function, social interaction, and self concept between elderly widow and elderly widower; and regression test to analyze the influence of characteristic of elderly, cognitive function and social interaction, to self concept of elderly widow and widower.

\section{Elderly Characteristics}

\section{RESULT}

The average age of the elderly widower (76.7 years) is slightly higher than the widowed elderly (73.5 years), the average length of education for the old widower is higher (5.0 years) than the widowed elderly (3.5 years), even the elderly widow and widower in this research including into the group did not complete primary school. Two-thirds of elderly widows $(66.7 \%)$ and nearly three-quarters of the widowed elderly (73.3\%) are not working, while nearly a quarter of the elderly widows $(20.0 \%)$ and less than a quarter of the widower elderly (16.7\%) are still actively earning their living as laborers as well as agricultural laborers. The average income earned by the elderly widower is lower, that is 406000 IDR compared with the average income of elderly widows of 509000 IDR. The test result of independent sample t-test shows that there is no difference characteristic between widowed widow and widower.

\section{Cognitive Function}

Table 1 shows that over half of the elderly widows are cognitively impaired while more than half of the widowed elderly have normal cognitive function. The independent test result of t-test shows that there is no difference of cognitive function between elderly widow and elderly widower. 
Table 1 The distribution of elderly by group of cognitive function and marital status

\begin{tabular}{lcccc}
\hline \multirow{2}{*}{ Cognitive function } & \multicolumn{2}{c}{ Widows } & \multicolumn{2}{c}{ Widowers } \\
\cline { 2 - 5 } & $\mathrm{N}$ & 53.3 & 12 & 40.0 \\
\hline Cognitive impairment $(<24)$ & 16 & 46.7 & 18 & 60.0 \\
Normal $(24-30)$ & 14 & 100.0 & 30 & 100.0 \\
\hline Total & 30 & $23.37 \pm 4.605$ & $22.57 \pm 6.135$ \\
Average \pm Deviation Standard & \multicolumn{3}{c}{0.309} \\
p-value & \multicolumn{4}{c}{} \\
\hline
\end{tabular}

\section{Social Interaction}

Table 2 shows nearly three-quarters of the widow's elderly and nearly twothirds of the widower elderly have social interactions in the medium group. The results of independent sample t-test showed no difference in social interaction between widowed widows and elderly widower.

Table 2 The distribution of elderly by goup of social interaction and marital status

\begin{tabular}{lcccc}
\hline \multirow{2}{*}{ Social interaction } & \multicolumn{2}{c}{ Widows } & \multicolumn{2}{c}{ Widowers } \\
\cline { 2 - 5 } & $\mathrm{n}$ & $\%$ & $\mathrm{n}$ & $\%$ \\
\hline Low $(<33.33)$ & 8 & 26.7 & 11 & 36.7 \\
Medium (33.33-66.67) & 22 & 73.3 & 18 & 60.0 \\
High (>66.67) & 0 & 0 & 1 & 3.3 \\
\hline Total & 30 & 100.0 & 30 & 100.0 \\
Average \pm Deviation Standard & $40.72 \pm 14.08$ & $38.16 \pm 14.64$ \\
p-value & \multicolumn{3}{c}{0.608} \\
\hline
\end{tabular}

\section{Self concept}

Table 3 shows that most elderly widows and widowers have self-concept in the medium group and the rest are in the high group. Different test results show that there are differences in self-concept between elderly widows and elderly widower.

Table 3 Distribution of the elderly by group of self-concept and marital status

\begin{tabular}{|c|c|c|c|c|}
\hline \multirow{2}{*}{ Group of Self-concept } & \multicolumn{2}{|c|}{ Widows } & \multicolumn{2}{|c|}{ Widower } \\
\hline & $\mathrm{N}$ & $\%$ & $\mathrm{n}$ & $\%$ \\
\hline Rendah $(<60)$ & 0 & 0.0 & 0 & 0.0 \\
\hline Sedang $(60-80)$ & 29 & 96.7 & 28 & 93.3 \\
\hline Tinggi $(>80)$ & 1 & 3.3 & 2 & 6.7 \\
\hline Low $(<33.33)$ & 30 & 100.0 & 30 & 100.0 \\
\hline Medium (33.33-66.67) & \multicolumn{2}{|c|}{$71.6 \pm 4.1$} & \multicolumn{2}{|c|}{$73.9 \pm 4.7$} \\
\hline High $(>66.67)$ & & & & \\
\hline
\end{tabular}

Description: * Significant at $\mathrm{p}<0.05$

\section{Relationships of Elderly Characteristic, Cognitive Functions, and Social Interactions, with Self-Concepts}

Correlation test results show that age has a significant negative relationship with cognitive function that means the increasing age of the elderly it will decrease its cognitive function. Conversely, the length of education has a significant positive relationship with cognitive function which means that the higher the elderly education the better the cognitive function. Even, social interactions are positively 
related to self-concept which means that the higher the social interaction of the elderly, the higher the self-concept (Table 4).

Table 4 The correlation coefficient between elderly characteristics, cognitive function, and social interaction with self-concept

\begin{tabular}{lccc}
\hline \multirow{2}{*}{ Variable } & \multicolumn{3}{c}{ Coefficient of correlation } \\
\cline { 2 - 4 } & Cognitive function & Social interaction & Self-concept \\
\hline Age (years) & $-0.400^{* *}$ & -0.177 & -0.096 \\
Lenght of education (years) & $0.580^{* *}$ & 0.201 & 0.076 \\
$\begin{array}{l}\text { Income } \\
\text { thousand/month) (IDR }\end{array}$ & 0.179 & 0.013 & -0.010 \\
$\begin{array}{l}\text { Cognitive function (index) } \\
\text { Social interaction (index) }\end{array}$ & 1 & & \\
\hline Den & 0.229 & 0.229 & 0.108 \\
\end{tabular}

Description: * significant at $\mathrm{p}<0.05 ; * *$ significant at $\mathrm{p}<0.01$

\section{Influence of Characteristics, Cognitive Function, Social Interaction of Self Concept}

The result of multiple linear regression test in Table 5 shows that marital status negatively affect self concept and social interaction have positive effect to self concept of elderly. The concept of self widower is higher by 2918 points of widowed elderly, and every increase one unit of social interaction of elderly hence can increase self concept equal to 0.095 point. Overall, the variables in this study had an effect of 11.2 percent in the regression model, the rest of 88.8 percent influenced by other variables outside the study.

Table 5 Multiple linear regression test results the effect of elderly's characteristic, cognitive function, social interaction on self concept

\begin{tabular}{lccc}
\hline Variable & $\begin{array}{c}\text { Unstandardized } \\
(\mathrm{B})\end{array}$ & $\begin{array}{c}\text { Standardized } \\
(\beta)\end{array}$ & Significant \\
\hline Constant & 68.459 & & \\
Lenght of education (years) & -0.148 & -0.129 & 0.420 \\
Marital status (0 = widower; 1 & -2.918 & -0.324 & $0.015^{*}$ \\
= widow) & & & \\
Cognitive function (index) & 0.064 & 0.139 & 0.378 \\
Social interaction (index) & 0.095 & 0.299 & $0.022^{*}$ \\
\hline Adjusted R square & & 0.112 & \\
F & & 2.863 & \\
Sig & & $0.032^{*}$ & \\
\hline
\end{tabular}

Description: * significant at $\mathrm{p}<0.05$

\section{DISCUSSION}

The results showed the average age of widows in the elderly group of 81.3 years and the elderly widower for 79.4 years with maximal age in the widowed widows reached 100 years and the elderly widower reached 94 years. Ministry of Health of the Republic of Indonesia (2013) state that the life expectancy of women is higher than men, so that women are able to reach a higher age than men with marital status as widows or widowers. But not a few elderly who still work like farm laborers, construction workers, clock repairs, coachman of horse-drawn carriage, self-employed and as a masseuse just to find activities just to stay healthy, 
but not a few elderly who still help his son's economy. Sidiarto and Kusumoputro (1999) stated that the work factor can accelerate the aging process, that is in the hard worker / over working such as the rough workers, farmers and laborers.

More than half widowed elderly (53.3\%) and less than half elderly widower (40\%) experienced a decrease in cognitive function. Petersen (2011) states that in middle age men are more at risk of decreased cognitive function while at a very old age women are more at risk of decreased cognitive function. Women tend to experience a decrease in cognitive function higher due to decreased estrogen hormone in menopausal women where the hormone has an important role in maintaining brain function (Hesti et al., 2008). Less than half elderly widows $(46.7 \%)$ and more than half of widower $(60 \%)$ have normal cognitive function.

More than a quarter $(26.7 \%)$ widowed elderly and more than one-third $(36.7 \%)$ elderly widower experienced low social interaction. According to the theory of liberation (Disengagement Theory) that with increasing age, a person gradually began to escape from his social life or withdraw from the association around him so as to result in age-old interaction decreased both in quality and quantity that can experience the loss of multiple loss of role, social contact, and reduced commitment (Cumming \& Henry 1961). Poor social interaction may be highly relevant for older adults because they have smaller social networks and fewer types of social relationships (Fung et al., 2001). Nearly three-quarters (73.3\%) of widowed and almost two-thirds $(60 \%)$ of widowed elderly have moderate social interaction, this is because the elderly still have the physical and psychic ability to interact with their environment. The results of this study are in line with the results of research Rosita (2012) that the elderly have a good social interaction ability $(58.8 \%)$ supported by the physical and psychological ability of the elderly. Kim et al. (2016) suggests that the majority of elderly people have positive social interactions and suggest that social interactions among older adults can be maintained or corrected through efforts to interact with the social environment even though aging is inevitable. Social interaction can cause a person to be close and to feel together or otherwise can make a person far and away from an interpersonal relationship (Wardhani et al., 2017).

All physical limitations that occur require adjustment through everyday activities can even lead to a change in self-concept that affects the psychosocial condition (Wijayanti et al., 2007). But with such conditions, more than threequarters of the elderly widows and widowers have self-concept in the medium group. This study is in accordance with Nisak (2013) that the concept of elderly self is in good group $(62.4 \%$ ) caused by confidence and always positive attitude shown by elderly in facing a failure. Elderly who has a good self-concept will be easier in appreciating himself and can see the positive things to do for the sake of survival and can accept the situation. The concept of self is involved in all aspects of psychological experience and so affects inter and intra personal behavior (Markus \& Kunda 1986; Markus \& Herzog 1991); thus the concept of self acts as a significant mediator of aging (Shu et al., 2003). Guptill (1969) states that people who find themselves as elderly have more negative self-concept than young people.

Different test results show that there is no difference between the cognitive function of elderly widows and widower because the elderly consider themselves not smart and feel unable to answer well so that the distribution of answers obtained 
did not differ greatly. In addition, elderly widows and widowers also have significant differences in self-ideal value, elderly widows have an average lower than the elderly widower. It is alleged that more than half of the widowed elderly do not often quarrel with their families to assume the behavior is in accordance with expectations, otherwise some elderly widows who are still fighting with his family. Ideal self-positive in the elderly is characterized by the success of the elderly in realizing the ideals and hopes of life so that the elderly feel satisfied and proud of his life. Individuals who have a good self-ideal will strive to meet ideal goals, aspirations, values, and standard of behavior, although aging and decreasing physical condition can degrade a person in the face of duty and meet the ideals or standard of living (Khairani 2012). In addition, there are differences in self-concept between elderly widows and elderly widower which means the concept of elderly widower is better than widowed widows. Women's weakness is related to their health because women's morbidity is higher and women tend to require more care in later life than men (Pinquart \& Sorensen 2001).

The results of correlation test performed showed that age has a significant negative relationship with cognitive function, it can be interpreted that the increasing age of the elderly it will decrease its cognitive function. According to Feldman et al. (2003) cognitive function of the elderly decreases with age. Cognitive function decreases with age (Ardiles et al. 2012) and aging are important factors for affecting cognitive function and early cognitive impairment in the elderly resulting in dementia (Sampedro-Piquero 2014). The duration of education also has a significant positive relationship with cognitive function, it can be interpreted that the higher education is achieved by the elderly it will be the higher the cognitive function. According to Rosita (2012) that education has a relationship with cognitive functioning because the level of education provides a lower risk of decreased cognitive function. The low risk of decline in cognitive function due to continuous education process in a person tends to have the ability to test its cognitive function. In addition, social interaction also has a significant positive relationship with self-concept, this means that the higher the social interaction will be the higher the concept itself. This is supported by Anwar's (2016) study stating that social interaction has a significant positive relationship with self-concept.

The results of multiple linear regression test states that the status of marriage and social interaction affect the self concept, this means that the status of widows can lower self-concept. Elderly with a widow's status has a less stable emotion and more easily experience stress so that it will affect the stability of self-concept (Kusfitadewi 2016). This is in line with the research of Hagborg et al (1993) in Oktaviani and Budiarti (2013) which states that men's self-concept is different from women, compared to men, women tend to express more concern and dissatisfaction with the body and overall physical appearance. Sari (2012) and Kusfitadewi (2016) stated that social interaction has an effect on self concept which makes elderly able to interact well in their environment and can well with the elderly so that the elderly can live a good old age. 


\section{Conclusion}

\section{CONCLUSION AND SUGGESTION}

The average age of widowed elderly (73.5 years) and widower ( 76.7 years) is over 70 years with most elderly are not working, and the average of elderly education does not complete primary school. The average of widow and widower elderly have decreased cognitive function in recall dimension, but in orientation, registration, and calculation and attention dimensions have improvement of cognitive function. The social interaction of elderly widow and widower is in moderate group with the highest mean of social interaction on the dimension of neighboring interaction, while the interaction dimension of nuclear family and interaction of old friend has the lowest average in elderly widower and dimension of social activity interaction in widowed elderly. Elderly and widower elderly have moderate self-concept with the highest mean on the dimension of self-identity, while the lowest average on self-role and self-image dimension. Cognitive function and social interaction do not have differences between elderly widow and widower, but the concept of elderly widower is higher than widowed elderly widow. Widow's status has relate and an effect on the decreasing of self concept, and social interaction is related and influence to the improvement of self concept. Widows have lower self-concept than elderly widower, and the better the social interaction hence the better self concept.

\section{Suggestion}

The elderly need to improve their social interaction especially with the nuclear family and relatives, and can play an active role in integrated coaching services or other social activities. In addition, the elderly should be active in social activities as well as do activities that can stimulate brain function, but it is better that activities that can stimulate brain function performed before entering the elderly so that it can inhibit the decline in cognitive function when it entered the elderly stage. Local governments play an active role to increase the the participation of integrated coaching services in order to improve the return of guidance programs to the elderly which aims to improve the psychosocial condition of the elderly and support the psychosocial condition of the elderly.

\section{REFERENCES}

Anwar, M.K. (2016). The relationship between self-concept and social interaction on nurses at Surakarta Islamic Hospital [Underthesis]. Surakarta (ID): University of Muhammadiyah Surakarta

Ardiles, A.O., Tapia-Rojas, C.C., Mandal, M. (2012). Postsynaptic dysfunction is associated with spatial and object recognition memory loss in a natural model of Alzheimer's disease. Proc Natl Acad Sci. 109: 13835-13840

[CBS] Central Bureau of Statistics. (2015). Elderly Population Statistics. Jakarta (ID): CBS

Desiningrum, D.R. (2014). Psychological welfare of elderly widow / widower viewed from perception to social support and gender. Journal of Psychology University of Diponegoro. 13 (2): 102-106 
Fadhia, N., Ulfiana, E., Ismono, S.R. (2012). Relationship of cognitive function with independence in doing activities of daily living (ADL) in elderly at UPT PSLU Pasuruan. Journal of Health [internet]. [downloads 2017 Jul 10]. Available at: http://journal.unair.ac.id/filerPDF/Najiyatul\%20F.docx

Feldman, H., Gautheir, S., Hecker, J. (2003). Efficacy of donepezil on maintenance of activities of daily living in patients with moderate to severe Alzhaeimer's disease and the effect on caregiver burden. J Am Geriats Soc 51: 737-744

Folstein, M., Folstein, S.E., McHugh, P.R. (1975). "Mini Mental State" a practical method for grading the cognitive state of patients for the clinician. Journal of Psychiatric Research 12(3): 189-198

Fung, H.H., Carstensen, L.L., Lang, F.R. (2001). Age-related patterns in social networks among European Americans and African Americans: implications for socioemotional selectivity across the life span. The International Journal of Aging and Human Development 52: 185-206

Guptill, C.S. (1969). A measure of age identification. Gerontologist 9: 96-102

Hesti, Harris, S., Mayza, A., Prihartono, J. (2008). Pengaruh gangguan kognitif terhadap gangguan keseimbangan pada lanjut usia. Artikel Penelitian Neurona 25(3): 26-31

Hesti, Harris, S., Mayza, A., Prihartono, J. (2008). The effect of cognitive impairment on balance disorders in the elderly. Neurona Research Articles. 25 (3): 26-31.

[Ministry of Health] Ministry of Health of the Republic of Indonesia. (2013). News Bulletin Data and Health Information. Jakarta (ID): Ministry of Health

Khairani. (2012). Self-concept and acceptance of aging process in pre-menopausal women at RSUDZA Banda Aceh. Idea Nursing Journal. 3 (2)

Kim, C., Wu, B., Tanaka, E., Watanabe, T., Watanabe, K., Chen, W., Ito, S., Okumura, R., Arai, T., Anme, T. (2016). Association between a change in social interaction among elderly people. International Journal of Gerontology 10: 76-80

Markus, H., Kunda, Z. (1986). Stability and malleability of the self-concept. Journal of Personality and Social Psychology 51(4): 858-866

Markus, H.Z., Herzog, A.R. (1991). The role of the self-concept in aging. Annual Review of Gerontology and Geriatrics 11: 110-143

Nisak, D.K. (2013). Relationship status self concept with the incidence of depression in the elderly at the Center for Social Services Tresna Werdha Khusnul Khotimah Pekanbaru [Underthesis]. Riau (ID): University of Riau

Oktaviani, A.E., Budiarti, A. (2013). Differences in self-concept between adolescent boys and girls at puberty [Underthesis]. Pekalongan (ID): Stikes Muhammadiyah Pekalongan

Parwiti, D. (2016). The relationship between self concept and social interaction in elderly in Posyandu Elderly Kemukus Village Gombong District Kebumen Regency [Underthesis]. Gombong (ID): Muhammadiyah Health Sciences College.

Petersen, R.C. (2011). Mild cognitive impairment. Journal of Medicine 364: 22272234 
Pinquart, M., Sorensen, S. (2001). Gender differences in self-concept and psychological well-being in old age: a meta-analysis. Journal of Gerontology: Psychological Sciences 56(4): 195-213

Rathus, S.A., Nevid, J.S. (1991). Abnormal psycology, ennglewood cliffs, prentice hall, new jersy in Semiun: Mental Health, Kanisius: Yogyakarta (ID)

Sampedro-Piquero, P., Bartolo, P.D., Petrosini, L. (2014). Astrocytic plasticity as a possible mediator of the cognitive improvements after environmental enrichment in aged rats. Neurobiol Learn Mem 114: 16-25

Sari, R.N. (2012). Relationship form of social interaction with quality of life in elderly [Underthesis]. Ponorogo (ID): University of Muhammadiyah Ponorogo.

Setyowati, S. (2013). Influence of self concept and socialization ability to quality of life of elderly. Journal of Midwifery and Nursing. 9 (2): 93-101

Shu, B.C., Huang, C., Chen, B.C. (2003). Factors related to self concept of elderly residing in a retirement center. Journal of Nursing Research 11(1): 1-7

Sidiarto, L.D., Kusumoputro, S. (1999). Mild cognitive impairment (MCI). NoeuroSains 1(1)

Wijayanti, R., Sahar, J., Sutanto. (2007). The relationship between family support through social interaction, transportation, financial and support efforts in preparing food in response to loss of the elderly in Pekaja Village, Kalibagor, Banyumas District. Nursing Journal of Soedirman. 2 (1)

Wardhani, D., Widodo, D., Widiani, E. (2017). The difference of satisfaction of women elderly social interaction in extrovert and introvert personality group at Panti Griya Asih Lawang Malang Regency. Nursing News. 2 (1) 